\title{
Metals and mineral phases of dusts collected in different urban parks of Krakow and their impact on the health of city residents
}

\author{
Alicja Kicińska $\cdot$ Piotr Bożęcki
}

Received: 18 October 2016/ Accepted: 9 March 2017/Published online: 14 March 2017

(C) The Author(s) 2017. This article is published with open access at Springerlink.com

\begin{abstract}
The authors present the results of chemical and mineralogical analyses of urban dusts collected in the spring seasons of 2015 and 2016 in three different parks of the Cracow agglomeration. The parks are located in the city centre, in the Nowa Huta industrial district and in a new housing development situated around $9 \mathrm{~km}$ west of the city centre. Mineralogical instrumental analyses included the SEM, FTIR and XRD methods and revealed that the dusts of Cracow are highly amorphous and contain significant amounts of hydrocarbons, whereas quartz, feldspars, kaolinite and gypsum are their crystalline phases. Chemical analyses were carried out using the ICP-MS method on aqua regia extracts of the starting samples. The contents of selected toxic elements are: As 5-123; Cd $1-14 ; \mathrm{Pb}$ 56-258; $\mathrm{Zn} \quad 486-1891 \mathrm{mg} / \mathrm{kg}$ and $\mathrm{Fe}$ 0.74-4.02 wt \%. The health risk of these elements imposed on the residents of Cracow frequently visiting the three urban parks was assessed on the basis of the health quotient index HQ. At its values exceeding 1, adverse health effects are probable in humans. The HQ values calculated for $\mathrm{As}$ and $\mathrm{Tl}$ contained in the Cracow Park dusts in the case of adults are 3.42E-01 and $3.00 \mathrm{E}-01$, respectively. They are significantly higher (one order of magnitude) in the case of children $3.19 \mathrm{E}+00$ and $2.27 \mathrm{E}+00$, respectively.
\end{abstract}

A. Kicińska $(\square) \cdot$ P. Bożęcki

AGH University of Science and Technology, Kraków,

Poland

e-mail: kicinska@geol.agh.edu.pl
Keywords Mineral phases - Dust - Urban parks · Health

\section{Introduction}

A civilization expansion of urban agglomerations gives not only considerable advantages but also a whole range of hazards (Skotak et al. 2012). One of the latter is contamination of the environment with toxic compounds of heavy metals (among others of $\mathrm{Cd}, \mathrm{Pb}$ and $\mathrm{Zn}$ ), metalloids (for instance As), and some organic and inorganic substances, which occur in air, water and soil. Their presence in the environment seriously threatens the health of living organisms. With regard to a human population, the health aspects include mainly reproductive problems, mental disorders, allergies, asthma and tumour incidences (Goudarzi et al. 2016; Khaniabadi et al. 2016). The WHO reported that environment-related diseases were responsible in 2010 for $15-20 \%$ of the total mortalities in Europe (Europe Environment 2010). The major reasons were identified as the suspended dusts $\mathrm{PM}_{10}$ and $\mathrm{PM}_{2.5}$, radonium, tobacco smoke and noise. Introducing technological improvements aimed at reducing emissions of dusts (mostly of the industrial origin) have brought about the expected effects in Europe, with regard particularly to the air pollution with $\mathrm{SO}_{2}, \mathrm{CO}$ and $\mathrm{NO}_{\mathrm{x}}$. However, in large agglomerations there are still growing numbers of vehicles 
used by public and private transport, and also they are a significant source of emissions of heavy metals (such as $\mathrm{Cr}, \mathrm{Ni}, \mathrm{Zn}$ and $\mathrm{Pb}$ ) resulting from fuel combustion and normal exploitation wear (Kicińska 2016a, b; Mazzei et al. 2008; Samek et al. 2016). It is a problem faced in most large towns located on almost all continents (WHO 2016). In the northern latitudes, the problem is not only a nuisance but becomes dangerous particularly in winter months, in which the permitted values of the $\mathrm{PM}_{10}$ and $\mathrm{PM}_{2.5}$ dusts are often exceeded even more than several times (Boldo et al. 2006; Moreno et al. 2011; Yu et al. 2013; Zhang et al. 2015).

Therefore, investigations of urban dusts within the area of Krakow, one of larger and the oldest European agglomerations, were carried out in the years 2015-2016 focusing on:

1. determination of the total contents of selected metals $(\mathrm{Cd}, \mathrm{Fe}, \mathrm{Hg}, \mathrm{Ni}, \mathrm{Pb}, \mathrm{Tl}, \mathrm{Zn})$ and a metalloid (As) related to exploitation of vehicles and combustion of solid fuels. They belong to the group of the elements of high toxicity, particularly to younger population;

2. identification of the dominating mineral phases that are carriers of selected metals in the urban dusts collected in three parks of Krakow;

3. establishing whether the metal-bearing forms occurring in the urban dusts are of the natural or anthropogenic origin.

The results of the chemical determinations were the basis of evaluating the health risk of the people spending much time in urban parks where they can be endangered due to a prolonged exposition to heavy metallic elements. This analysis was conducted calculating the so-called hazard quotient (HQ).

\section{Research area}

The Krakow agglomeration covers 327 square km, of which $4.3 \%$ are forested. Its number of permanent population in 2014 was 762,000 at the positive birth rate $0.6 \%$ (GUS 2015). During 10-11 months, the city is additionally inhabited by around 300,000 students. Each year Krakow is also visited by tourists and other newcomers: in 2015 slightly above 10 million people (foreigners exceeding 50\%) paid short visits to Krakow (www.krakow/pl). The city plays a cultural and educational role but is also an important industrial centre. In the last 10 years, the production manufactured and sold by various enterprises of Krakow has jumped from 12,928 to 28,044 million PLN (GUS 2015), proving a dynamic increase in this sector. An efficient existence of any larger agglomeration requires the presence of a passable road network, whose length in the Krakow area in 2014 was $294 \mathrm{~km}$ per $100 \mathrm{~km}^{2}$. If compared with the respective data for 2005, the total length of city roads and streets increased by a mere $7 \%$ in 2014 (from 898 to $960 \mathrm{~km}$, respectively), whereas the number of cars licensed in the Małopolska Voivodeship (Krakow is its capital town) by more than $50 \%$. These are mainly passenger cars, which in Krakow make $76 \%$ of all the vehicles owned by town residents. Adding a long-distance movement of vehicles and the lack of ring roads, there is nothing strange that major thoroughfares are overloaded not only during rush hours.

In Krakow, there are 24 enterprises particularly affecting the air quality: 13 of them are equipped with the installations reducing dust contaminants and only two with the installations cleaning gaseous contaminants. In 2015, nine of them did not have internal stations measuring dust emissions and seven the emissions of gases, while emissions (i.e. overall deposition of contaminants from any own and outer sources) was measured on the premises of three of them (GUS 2015).

The total of dust emissions within the Krakow area in 2012 was $1900 \mathrm{Mg}$ (4400 Mg in 2005), and out of it the dusts generated by combustion of car fuels made $0.900 \mathrm{Mg}$. The gaseous contaminants, excluding $\mathrm{CO}_{2}$, reached $28,500 \mathrm{Mg}$, broken down into $32 \% \mathrm{SO}_{2}, 42 \%$ $\mathrm{CO}$ and $22 \% \mathrm{NO}_{\mathrm{x}}$, accompanied by $\mathrm{H}_{2} \mathrm{~S}, \mathrm{~N}_{2} \mathrm{O}, \mathrm{NH}_{3}$, $\mathrm{HCl}, \mathrm{HF}$ and hydrocarbons. Although almost $99 \%$ of the dusts were caught in dust-reducing installations, only $1.1 \%$ gaseous products were stopped from going into the air. The quality of the air of Krakow is a serious issue and a subject of many papers (e.g. Rzeszutek et al. 2014; Kicińska and Klimek 2017; Samek et al. 2016) and reports of specialized state units (e.g. www.krakow.pios.gov.pl). Part of respective reports is devoted to the impact of such factors as the diameter of aerosol particles, their concentration and chemical composition on the health of the Krakovians. Some contaminants inhaled with the air may be dissolved in body fluids (in bronchial mucus), and after entering the blood circulation system they reach other organs. The process is particularly 
dangerous in the prenatal period of a child development. Research of Jędrychowski and its team in the years 2000-2004 shown that the newborns whose mothers lived in Krakow throughout the whole pregnancy were (on the average) lighter by $128 \mathrm{~g}$ and shorter by $0.9 \mathrm{~cm}$ and had their head perimeter shorter by $0.3 \mathrm{~cm}$ in comparison with those born in non-polluted regions. The so-called whistling breathing is more often observed in the children with a lower birth body mass, which is a significant herald of possible asthmatic problems in the future. In a further development of such youngsters, the following findings were noted (Jedrychowski et al. 2008): lower values of their lung expiratory volume by around $100 \mathrm{ml}$, recurrent infections of the respiratory system (five times higher frequency of bronchi inflammation), and lower parameters of their psycho-motoric development (an average of 3.8 points on the scale of the intelligence quotient index IQ).

Despite introducing many preventive and reducing measures to control the quantity of pollutants in the Krakow air, the results of its monitoring still arise much anxiety of the city residents (Table 1). The statistics for 2010-2015 quote for some districts as many as 200 days per year in which the permissible air levels of $\mathrm{NO}_{2}$, suspended $\mathrm{PM}_{10}$ and $\mathrm{PM}_{2.5}$ particulates, and the content of the $\mathrm{B}(\mathrm{a}) \mathrm{P}$ [benzo( $\alpha$ )pyrene] in the suspended $\mathrm{PM}_{10}$ particulates were exceeded. Seasonal

Table 1 Air quality parameters in Cracow in May 2015 and 2016 (data of the State Air Monitoring, Krakow 2015-2016)

\begin{tabular}{|c|c|c|c|c|c|c|c|c|c|c|}
\hline $\begin{array}{l}\text { Location of the } \\
\text { monitoring stations }{ }^{a}\end{array}$ & Year & Parameter & $\begin{array}{l}\mathrm{SO}_{2} \\
\left(\mu \mathrm{g} / \mathrm{m}^{3}\right)\end{array}$ & $\begin{array}{l}\mathrm{NO}_{2} \\
\left(\mu \mathrm{g} / \mathrm{m}^{3}\right)\end{array}$ & $\begin{array}{l}\mathrm{NO}_{\mathrm{x}} \\
\left(\mu \mathrm{g} / \mathrm{m}^{3}\right)\end{array}$ & $\begin{array}{l}\text { NO } \\
\left(\mu \mathrm{g} / \mathrm{m}^{3}\right)\end{array}$ & $\begin{array}{l}\mathrm{CO} \\
\left(\mu \mathrm{g} / \mathrm{m}^{3}\right)\end{array}$ & $\begin{array}{l}\mathrm{C}_{6} \mathrm{H}_{6} \\
\left(\mu \mathrm{g} / \mathrm{m}^{3}\right)\end{array}$ & $\begin{array}{l}\mathrm{PM}_{10} \\
\left(\mu \mathrm{g} / \mathrm{m}^{3}\right)\end{array}$ & $\begin{array}{l}\mathrm{PM}_{2.5} \\
\left(\mu \mathrm{g} / \mathrm{m}^{3}\right)\end{array}$ \\
\hline \multirow{4}{*}{$\begin{array}{l}\text { Al. Krasickiego } \\
\text { Park no. I }\end{array}$} & \multirow[t]{2}{*}{2015} & Average $^{\mathrm{d}}$ & - & 70 & 208 & 90 & 697 & - & 45 & 27 \\
\hline & & Min.-max. & - & $51-88$ & $106-297$ & $36-149$ & $376-972$ & - & $27-60$ & $17-40$ \\
\hline & \multirow[t]{2}{*}{2016} & Average & - & 64 & 189 & 82 & 715 & 1.1 & 46 & 28 \\
\hline & & Min.-max. & - & $38-84$ & $91-274$ & $34-137$ & $448-971$ & $0.6-1.8$ & $23-94(10)^{\mathrm{c}}$ & $14-47$ \\
\hline \multirow{4}{*}{$\begin{array}{l}\text { Nowa Huta } \\
\text { Park no. II }\end{array}$} & \multirow[t]{2}{*}{2015} & Average & 6.2 & 27 & 44 & 11 & 455 & 1.5 & 31 & 19 \\
\hline & & Min.-max. & $2.3-13.3$ & $8-42$ & $9-79$ & $1-29$ & $261-726$ & $0.6-2.6$ & $14-53(1)^{\mathrm{c}}$ & $9-33$ \\
\hline & \multirow[t]{2}{*}{2016} & Average & 5.4 & 23 & 37 & 9 & 449 & 1.3 & 25 & 16 \\
\hline & & Min.-max. & $1.5-10.0$ & $11-40$ & $11-88$ & $0-34$ & $276-842$ & $0.4-3.0$ & $13-46$ & $8-36$ \\
\hline \multirow[t]{4}{*}{ Skawina Park no. III } & \multirow[t]{2}{*}{2015} & Average & 7.4 & 19 & 26 & 5 & - & - & 25 & - \\
\hline & & Min.-max. & $1.4-22.7$ & $10-28$ & $12-43$ & $1-13$ & - & - & $13-37$ & - \\
\hline & \multirow[t]{2}{*}{2016} & Average & 4.2 & 18 & 24 & 4 & - & - & 25 & - \\
\hline & & Min.-max. & $1.5-14.9$ & $9-25$ & $11-42$ & $1-13$ & - & - & $15-37$ & - \\
\hline \multicolumn{11}{|l|}{ Upper limits during ${ }^{\mathrm{b}}$} \\
\hline \multicolumn{3}{|l|}{$1 \mathrm{~h}$} & 350 & 200 & & nd & nd & nd & 50 & nd \\
\hline \multicolumn{3}{|l|}{$8 \mathrm{~h}$} & nd & nd & & nd & 10,000 & nd & nd & nd \\
\hline \multicolumn{3}{|l|}{$24 \mathrm{~h}$} & 125 & nd & & nd & nd & nd & nd & nd \\
\hline \multicolumn{3}{|l|}{1 year } & 20 & 40 & & 30 & nd & 5 & 40 & 20 \\
\hline \multicolumn{11}{|l|}{ "_" not measured } \\
\hline \multicolumn{11}{|l|}{ "nd" no data } \\
\hline \multicolumn{11}{|c|}{ a Monitoring stations located in the nearest distance from the urban parks considered } \\
\hline \multicolumn{11}{|c|}{ b According to Regulation of the Minister of the Environment on the level of some substances in the air. Dz. U. poz.1031 } \\
\hline \multicolumn{11}{|c|}{ c The number of days in which the upper limits were exceeded } \\
\hline
\end{tabular}


variations of the $\mathrm{PM}_{2.5}$ concentration of $\mathrm{Cl}, \mathrm{K}, \mathrm{Br}, \mathrm{Pb}$, $\mathrm{Cu}$ and $\mathrm{Zn}$ were reported by Samek et al. (2016). They also identified seven indicators (pollutants) that allow attributing a single pollution source to each one of them. The sources distinguished (op. cit.) are: steel industry, traffic (diesel and gasoline exhaust gases), road dusts, construction dusts, soil dusts, combustion of coal and/or biomass, non-ferrous metallurgical industry.

\section{Materials and methods}

The material investigated represents urban atmospheric dusts collected in the spring months (May) of 2015 and 2016 in three city parks numbered I-III (Fig. 1). The selection of sampling sites was based on the results published by Samek et al. (2016) and pertaining to the contents of major and trace element in the PM2.5 during different seasons of the 2014/2015 period in Krakow. In the winter time, the amount of airborne dusts increases due to combustion of coal and biomass fuels, which results in increasing emissions of $\mathrm{Cl}, \mathrm{K}, \mathrm{Cr}, \mathrm{Mn}, \mathrm{Cu}, \mathrm{Zn}, \mathrm{Br}, \mathrm{Rb}$ and $\mathrm{Pb}$. However, because of weather conditions children do not spent much time in urban parks. In contrary, the emissions are lower in summer months, but children frequently visit and play in the parks and it may be assumed that the health risks during winter and summer months are comparable. Accordingly, also comparable should be the spring and autumn.

In every park, nine dust samples with a weight around $100 \mathrm{mg}$ each were collected from outer

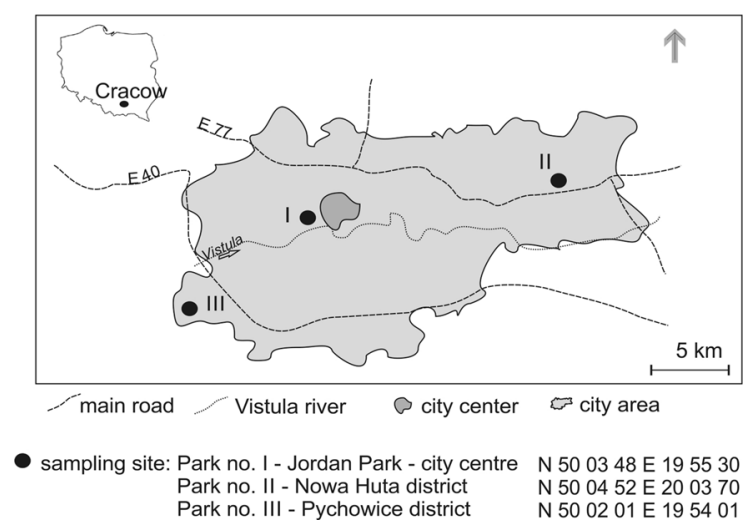

Fig. 1 Location of sampling sites within the limits of the Cracow city surfaces of recreational and sport facilities by rinsing them with distilled water ("wet method") and by brushing ("dry method"). The two techniques were applied because of the research approach. The samples designated to chemical determinations were collected with the "wet method" by rinsing only those parts of the playing facilities that come into the contact with children hands: it has been assumed that only this part of dusts should be considered in HQ calculations. The solutions were next evaporated to dry mass on a water bath and the solid samples used for chemical determinations. The samples to be studied with the XRD, SEM and FTIR methods were collected as a freefalling dust deposited from the ambient air on singlestage impactors lined with a paper filter ("dry method").

Park no. I: The Jordan Park represents the city centre and is located around $2 \mathrm{~km}$ from the historic Main Market. The area around has the highest traffic load of moving vehicles, and the park itself is one of the oldest and most popular resting places of the Krakow residents.

Park no. II: The Nowa Huta Park represents the industrial part of Krakow and is located around $1 \mathrm{~km}$ from the ArcelorMittal Poland plant. The plant is a metallurgical facility (formerly the Tadeusz Sendzimir Steelworks) producing annually around $1.3 \mathrm{mln}$ $\mathrm{Mg}$ of steel. Its annual emissions are: $2.7 \mathrm{mln} \mathrm{Mg}$ of $\mathrm{CO}_{2} ; 2407 \mathrm{Mg}$ of $\mathrm{NO}_{\mathrm{x}} ; 4236 \mathrm{Mg}$ of $\mathrm{SO}_{\mathrm{x}}$ and above $450 \mathrm{Mg}$ of suspended dust (Sustainability Report 2014).

Park no. III: Located in a modern housing development of Pychowice, a district distant at around $9 \mathrm{~km}$ to SW of the city centre.

The methods of X-ray diffractometry (XRD), Fourier transformed infrared spectroscopy (FTIR) and scanning electron microscopy (SEM) were used to determine the phase composition of dust particles, and SEM also to observe the surface morphology. Applying a one-step extraction of metals with concentrated acids $\left(\mathrm{HNO}_{3}+\mathrm{HCl}+\mathrm{HClO}_{4}\right)$ at a ratio of the solid phase (dust) to the liquid phase (mixture of acids) of 1:10, sample eluates were obtained. Their chemical composition was determined using the method of induced coupled plasma mass emission spectroscopy (ICP-MS) at the certified hydrogeochemical laboratory (certificate of the Polish Accreditation Commission no. AB1050) of the AGH University of Science and Technology in Krakow. 
The precision of the determining $\mathrm{Fe}, \mathrm{Ca}, \mathrm{Al}, \mathrm{K}, \mathrm{Mg}$, Si, $\mathrm{Mn}, \mathrm{Na}, \mathrm{Zn}, \mathrm{Ba}, \mathrm{Pb}, \mathrm{As}, \mathrm{Ti}, \mathrm{Cd}, \mathrm{Ni}, \mathrm{Tl}, \mathrm{Cr}$ and $\mathrm{Co}$ was $10 \%$, while the accuracies ranged between 95 and $105 \%$. The limits of detection (LOD) and quantification (LOQ) parameters were calculated from the following equations:

$\mathrm{LOD}=X_{\mathrm{b}}+3 \mathrm{SD}_{\mathrm{b}}$,
$\mathrm{LOQ}=X_{\mathrm{b}}+10 \mathrm{SD}_{\mathrm{b}}$,

where $X_{\mathrm{b}}$, mean concentration of the blank (zero concentration) sample; $\mathrm{SD}_{\mathrm{b}}$, the standard deviation of the blank; and their values are presented in Table 2.

Statistical calculations and data presentation were conducted with the Statistica version 10 and Excel applications. The group analyses were based on variables (concentrations of elements) characterising the objects considered (i.e. parks) and allowed distinguishing the groups (clusters), inside which the parameters selected are more similar within the given group than to the parameters within other groups. This type of the analysis allows detecting whether the groups reveal any regularity (correlation) and reduces the databases to the averages calculated for specific groups. The Ward method is an analysis of a variance problem, based on minimizing totals of square deviations within the groups (clusters). The method accumulates into clusters the cases with minimum diversifications.

The phase composition of crystalline components was carried out applying the powder Debye-Scherrer method using a Rigaku MiniFlex 600 XRD diffractometer. The measurement parameters were as follows: $\mathrm{CuK}_{\alpha}$ radiation, reflection graphitic monochromator, lamp voltage $40 \mathrm{kV}$, lamp current $20 \mathrm{~mA}$, recording range $2^{\circ}-72^{\circ} 2 \Theta$; step $0.05^{\circ} 2 \Theta$, impulse count rate $1 \mathrm{sek} / \mathrm{step}$. The interplanar distances obtained from the $\mathrm{X}$-rays patterns were used for

Table 2 Chemical composition of dust samples from Krakow

\begin{tabular}{|c|c|c|c|c|c|c|c|}
\hline \multirow[t]{2}{*}{ Element } & \multirow[t]{2}{*}{$\operatorname{LOD}\left(\mathrm{mg} / \mathrm{dm}^{3}\right)$} & \multirow[t]{2}{*}{$\mathrm{LOQ}\left(\mathrm{mg} / \mathrm{dm}^{3}\right)$} & \multirow{2}{*}{$\begin{array}{l}\text { Park no. I } \\
\text { Min.-max. } \\
n=9\end{array}$} & \multirow{2}{*}{$\begin{array}{l}\text { Park no. II } \\
\text { Min.-max. } \\
n=9\end{array}$} & \multirow{2}{*}{$\begin{array}{l}\text { Park no. III } \\
\text { Min.-max. } \\
n=9\end{array}$} & \multicolumn{2}{|c|}{ All dust samples } \\
\hline & & & & & & $\begin{array}{l}\text { Min.-max. } \\
n=27\end{array}$ & $x \pm \mathrm{SD}$ \\
\hline Main & & & & & $(w t \%)$ & & \\
\hline $\mathrm{Fe}$ & 0.0094 & 0.0176 & $2.73-2.92$ & $0.74-4.02$ & $1.11-1.53$ & $0.74-4.02$ & $2.17 \pm 1.1$ \\
\hline $\mathrm{Ca}$ & 0.0213 & 0.0314 & $1.13-1.78$ & $0.41-1.69$ & $0.49-0.55$ & $0.41-1.78$ & $1.01 \pm 0.6$ \\
\hline $\mathrm{Al}$ & 0.0071 & 0.0091 & $0.89-0.98$ & $0.25-0.41$ & $0.32-0.34$ & $0.25-0.98$ & $0.53 \pm 0.3$ \\
\hline $\mathrm{K}$ & 0.2506 & 0.2848 & $0.34-0.56$ & $0.06-0.17$ & $0.11-0.14$ & $0.05-0.56$ & $0.23 \pm 0.1$ \\
\hline $\mathrm{Mg}$ & 0.0029 & 0.0049 & $0.44-0.66$ & $0.11-0.66$ & $0.18-0.22$ & $0.11-0.66$ & $0.38 \pm 0.2$ \\
\hline $\mathrm{Si}$ & 0.0083 & 0.0674 & $0.79-3.44$ & $0.04-0.15$ & $0.07-0.15$ & $0.04-3.44$ & $0.78 \pm 1.2$ \\
\hline Trace & & & & & $(\mathrm{mg} / \mathrm{kg})$ & & \\
\hline $\mathrm{Na}$ & 0.0620 & 0.1099 & 1079-2826 & $96-837$ & $504-692$ & $96-2826$ & $1006 \pm 869$ \\
\hline $\mathrm{Zn}$ & 0.0290 & 0.1159 & $907-1335$ & 561-1891 & $486-558$ & 486-1891 & $956 \pm 509$ \\
\hline $\mathrm{Mn}$ & 0.0014 & 0.0034 & $524-758$ & $216-687$ & $284-329$ & $216-758$ & $467 \pm 205$ \\
\hline $\mathrm{Ba}$ & 0.0064 & 0.0213 & $191-1403$ & $44-843$ & $69-151$ & $44-1403$ & $450 \pm 505$ \\
\hline $\mathrm{Ti}$ & 0.0004 & 0.0011 & $359-479$ & $18-256$ & $101-129$ & $18-479$ & $224 \pm 159$ \\
\hline $\mathrm{Pb}$ & 0.0047 & 0.0463 & 201-204 & $56-208$ & $213-258$ & $56-258$ & $190 \pm 63$ \\
\hline As & 0.1046 & 0.2655 & $76-123$ & $5-31$ & $105-107$ & $5-123$ & $75 \pm 43$ \\
\hline $\mathrm{Cr}$ & 0.0016 & 0.0064 & $68-87$ & $13-85$ & $65-67$ & $13-87$ & $64 \pm 24$ \\
\hline $\mathrm{Ni}$ & 0.0065 & 0.0196 & $29-56$ & $8-30$ & $15-226$ & $8-226$ & $61 \pm 75$ \\
\hline $\mathrm{Co}$ & 0.0038 & 0.0097 & $20-52$ & $3-140$ & $2-39$ & $2-140$ & $43 \pm 47$ \\
\hline $\mathrm{Tl}$ & 0.0120 & 0.0421 & bdl-18 & bdl-1.4 & $33-53$ & bdl-53 & $17 \pm 20$ \\
\hline $\mathrm{Cd}$ & 0.0013 & 0.0029 & $6-14$ & $1-5$ & $5-6$ & $1-14$ & $6 \pm 4$ \\
\hline $\mathrm{Hg}$ & 0.0054 & 0.0340 & bdl- -4.7 & bdl- -0.6 & bdl-3.7 & bdl-4.7 & $1.5 \pm 2$ \\
\hline
\end{tabular}

$L O D$ limit of detection, $L O Q$ limit of quantitation, $x$ arithmetic average, $S D$ standard deviation for the whole population $(n=27)$, $n$ number of samples, $b d l$ below the detection limit 
identifying crystalline phases based on the data of the ICDD (International Centre for Diffraction Data) catalogue and the XRAYAN software.

The infrared absorption spectra were recorded within the range from 4000 to $400 \mathrm{~cm}^{-1}$ with a resolution of $4 \mathrm{~cm}^{-1}$ using a FTIR model FTS 165 spectrometer (made by BIO-RAD). The samples had a form of tablets pressed at $10 \mathrm{MPa}$ from a powdered mixture of $0.5 \mathrm{mg}$ of the sample and $200 \mathrm{mg}$ of spectrally pure potassium bromide $(\mathrm{KBr})$.

The quantity of hydrocarbons was determined with a FTIR spectrometer model FTS 165. The samples measured were organic extracts obtained by treating starting samples with tetrachloroethylene at a solid-toliquid ratio of 1:20. The determinations were carried out according to the DIN 38409, H. 18 standard. The concentrations of aliphatic and aromatic hydrocarbons are based on the intensities of respective absorption bands of the $\mathrm{CH}_{2}, \mathrm{CH}_{3}$ and $C_{\text {arom. }}$ groups.

The morphology of dust components was determined using a FEI Quanta model 200 FEG scanning electron microscope. The observations were extended by chemical analyses of microareas applying an EDS detector (SEM-EDS method) conducted in the high vacuum mode. The resolution power of the microscope was increased by covering the samples with carbon prior to analysing. The accelerating voltage was $20 \mathrm{kV}$.

The health risk index HQ from a prolonged exposition to heavy metals was calculated using the equation of Leung et al. (2008) as HQ = ADD/RfD, where ADD—average daily dose, and RfD—reference dose (in $\mathrm{mg} / \mathrm{kg}$ per day). The ADD value was calculated from the following equation (Wcisło 2009; US EPA 1986):

$\mathrm{ADD}=\frac{C \cdot \operatorname{lngR} \cdot \mathrm{EF} \cdot \mathrm{ED}}{\mathrm{BW} \cdot \mathrm{AT}} \cdot \mathrm{CF} 1$,

where $C$ mean heavy metal concentration in the dust $(\mathrm{mg} / \mathrm{kg})$; IngR, conservative estimates of dust ingestion rates, accepted for children as $200 \mathrm{mg}$ per day and for adults as $100 \mathrm{mg}$ per day; $\mathrm{EF}$, exposure frequency, accepted as 350 days/year; ED, exposure duration, accepted as 6 years for children and 70 years for adults; BW, body weight, accepted as $15 \mathrm{~kg}$ for children and $70 \mathrm{~kg}$ for adults; AT, averaging time, accepted as 6365 days for children 6 years old and 70,365 days for adults 70 years old.CF1, unit conversion factor of $10^{-6}$.
The values HQ $\leq 1$ suggest a low probability of health risk, the values HQ $>1$ mean a probability of negative health effects. The values $\mathrm{HQ}>10$ are considered high, resulting in a chronic health risk caused by exposition of toxicants.

\section{Phase composition and morphology of the urban dusts of Krakow}

X-ray diffraction analyses

X-ray diffraction of the dust fallouts shows a substantial differentiation of their crystalline components (Fig. 2). The samples from the Jordan Park (Fig. 2I) and Pychowice (Fig. 2III) contain highly crystalline mineral phases: quartz $\mathrm{SiO}_{2}$, which is the major mineral of both sites, sodium-calcium feldspars (plagioclases) $\mathrm{Na}\left[\mathrm{AlSi}_{3} \mathrm{O}_{8}\right]-\mathrm{Ca}\left[\mathrm{Al}_{2} \mathrm{Si}_{2} \mathrm{O}_{8}\right]$ and potassium feldspars $\mathrm{K}\left[\mathrm{AlSi}_{3} \mathrm{O}_{8}\right.$ ], accompanied by minor amounts of calcite $\mathrm{CaCO}_{3}$. Additionally, gypsum

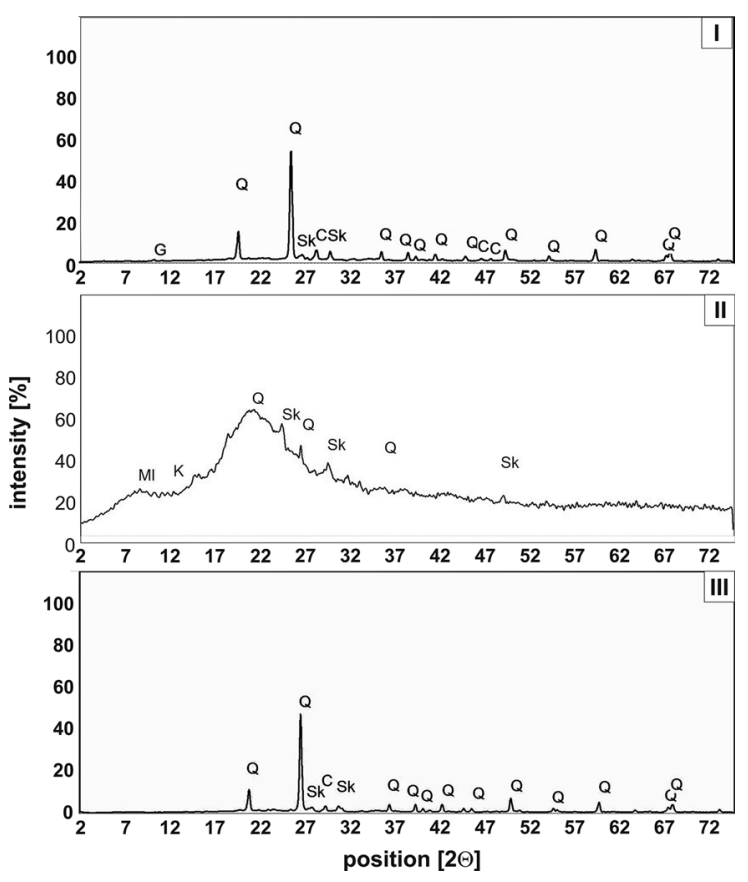

Fig. 2 XRD patterns of urban atmospheric dust samples collected in: I-Jordan Park, II-Nowa Huta Park, IIIPychowice Park (Q-quartz, Sk—feldspar, C—calcite, Mlmuscovite, $\mathrm{G}$-gypsum) 
$\mathrm{CaSO}_{4} \cdot 2 \mathrm{H}_{2} \mathrm{O}$ is present in the sample from the Jordan Park (park no. I).

The X-ray patterns of the airborne dusts from the district Nowa Huta (park no. II) have significantly elevated diffraction backgrounds (Fig. 2II), which indicates the presence of a highly amorphous material. Amorphisation of the particulate matter usually proves its anthropogenic origin. Of the crystalline phases, quartz was identified without any doubts, and probable trace minerals include feldspars and clay minerals of the kaolinite group $\left(\mathrm{Al}_{4}\left[\mathrm{Si}_{4} \mathrm{O}_{10}\right](\mathrm{OH})_{8}\right)$.

Silicate and aluminosilicate components (quartz and feldspars) are mostly primary minerals of the geogenic origin. The prevalence of quartz may be explained by blowing away psammitic-aleuritic grain fractions $(2-0.1 \mathrm{~mm})$ of sand from nearby sandboxes that are a typical playing facility of city parks.

The remaining, minor mineral phases were identified as carbonates (mainly calcite) and sulphates (finegrained gypsum). The latter is a typical secondary component of airborne dusts formed due to the socalled salt weathering, i.e. the reaction of sulphuric acid (derived from atmospheric $\mathrm{SO}_{2}$ ) with carbonate minerals.

\section{Infrared spectroscopic analyses (FTIR)}

The spectra of the samples collected in the Jordan Park (Fig. 3, no. I) show a considerable contamination of dusts with hydrocarbons, whose diagnostic, intensive absorption bands occur between 2960 and $2850 \mathrm{~cm}^{-1}$. The presence of hydrocarbons most probably results from a considerable movement of vehicles in this city area. Among mineral phases, the dusts of the Jordan Park contain gypsum (absorption bands 1160 and $1100 \mathrm{~cm}^{-1}$ ), quartz/opal (intensive absorption bands around 1070, 770 and $460 \mathrm{~cm}^{-1}$ ) and muscovite/illite (intensive absorption bands around 3440, 1630, 1080, 520 and $\left.465 \mathrm{~cm}^{-1}\right)$.

Calcite (absorption bands around 3440, 1420 and $700 \mathrm{~cm}^{-1}$ ) and gypsum (absorption bands 1620, 1160, 1100650 and $600 \mathrm{~cm}^{-1}$ ) have been identified in the spectra of the dust samples of the park in Nowa Huta (Fig. 3, no. II). These mineral phases are accompanied by minor amounts of quartz and layered aluminosilicates of the muscovite/illite type. The dusts also contain traces of hydrocarbons, marked by distinct bands in the range $2930-2860 \mathrm{~cm}^{-1}$.
The phase composition of dust samples collected in the park in Pychowice (Fig. 3, no. III) is comparable to that of the Jordan Park. Mineral phases include quartz, calcite and layered aluminosilicates of the muscovite/ illite type, all of them most probably of the geogenic origin. The dusts of Pychowice contain traces of hydrocarbons, occurring in the lowest quantities of the three parks considered. Low quantities of these oilderived contaminants are a proof of low pollution of the Pychowice area by the motor traffic.

\section{Hydrocarbons in urban dusts (FTIR analyses)}

Extraction of airborne dusts with tetrachloroethylene aimed at the quantification and identification of hydrocarbons released into the atmosphere by combustion of motor fuels. The highest amounts $(6927 \mathrm{mg} / \mathrm{kg}$ ) were found in the dusts of the Jordan Park. It is mainly the mineral oil $(6924 \mathrm{mg} / \mathrm{kg})$, accompanied by traces of benzine $(3.3 \mathrm{mg} / \mathrm{kg})$. In the dust collected in Nowa Huta, the total of hydrocarbons was 4.5 times lower $(1564.15 \mathrm{mg} / \mathrm{kg})$ : the mineral oil contributes $1563.722 \mathrm{mg} / \mathrm{kg}$, while benzine occurs in traces $(0.435 \mathrm{mg} / \mathrm{kg})$. The dust content of hydrocarbons was the lowest in Pychowice: the mineral oil prevails $(1047.8 \mathrm{mg} / \mathrm{kg})$, while benzine occurs in traces $(0.2 \mathrm{mg} / \mathrm{kg})$.

The contents of hydrocarbons in the dust fallouts compared with the limits of hydrocarbons in soils (the Regulation of the Minister of the Environment of 2002) indicate a significant contamination of the parks with oil-derived substances. The limit of benzines in the soils of the A-type areas, i.e. those under the legal protection, is $1 \mathrm{mg} / \mathrm{kg}$, and of mineral oils $30 \mathrm{mg} / \mathrm{kg}$. The remaining soils of groups $\mathrm{B}$ and $\mathrm{C}$ have the upper limits of benzines $1-750 \mathrm{mg} / \mathrm{kg}$ and of mineral oils $50-3000 \mathrm{mg} / \mathrm{kg}$, depending on the depth of soil sampling and water permeability of the soils.

\section{Scanning electron microscopy (SEM-EDS)}

The SEM images and point EDS chemical determinations confirm that the dusts contain both the geogenic material, mainly quartz grains, and the substances of the secondary, anthropogenic origin, i.e. hydrocarbons and gypsum.

The dusts collected in the Jordan Park (Fig. 4) reveal the presence of large grains $(20-100 \mu \mathrm{m})$, angular with irregular shapes, and of spherical and 


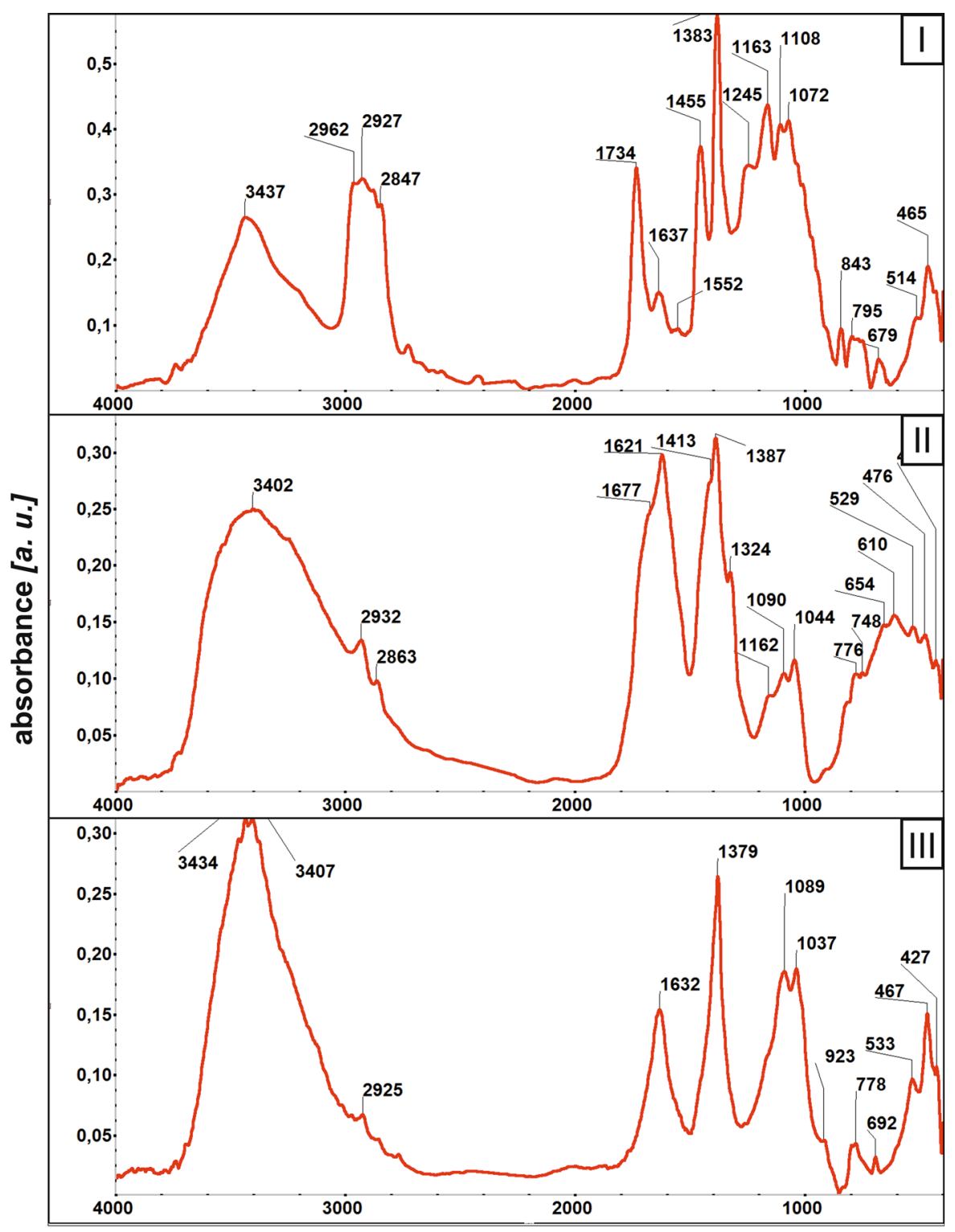

wavenumbers $\left[\mathrm{cm}^{-1}\right]$

Fig. 3 FTIR spectra of the urban atmospheric dust samples, I-Jordan Park; II—Nowa Huta Park; III-Pychowice Park

oval forms with diameters of around 10-20 $\mu \mathrm{m}$. They are interspersed in a very fine $(<1 \mu \mathrm{m})$ carbonatesiliceous mass. The irregular grains represent mainly quartz, a few of them possibly also feldspars (point 2, Fig. 4). Some of them are coated with very finegrained $(0.5-1 \mu \mathrm{m})$ prismatic or acicular, secondary gypsum crystals. The spherical forms (point 3, Fig. 4) are fragments of partly burned coal and are signs of deposition of dusts attributable to the low emission. Their contribution to the total number of the particulate matter is rather large. The spheres are also often covered with fine-crystalline gypsum crystals. A grain smaller $(5-10 \mu \mathrm{m})$ than the other particles and differing from them due to its white colour in the SEM image (point 1, Fig. 4) represents an aggregate composed of oxides and hydro-oxides of iron.

The dust particles of the Nowa Huta Park show a considerable fragmentation of quartz and feldspar grains (Fig. 5) that are dominating components. These autogenic silicate and aluminosilicate minerals are 

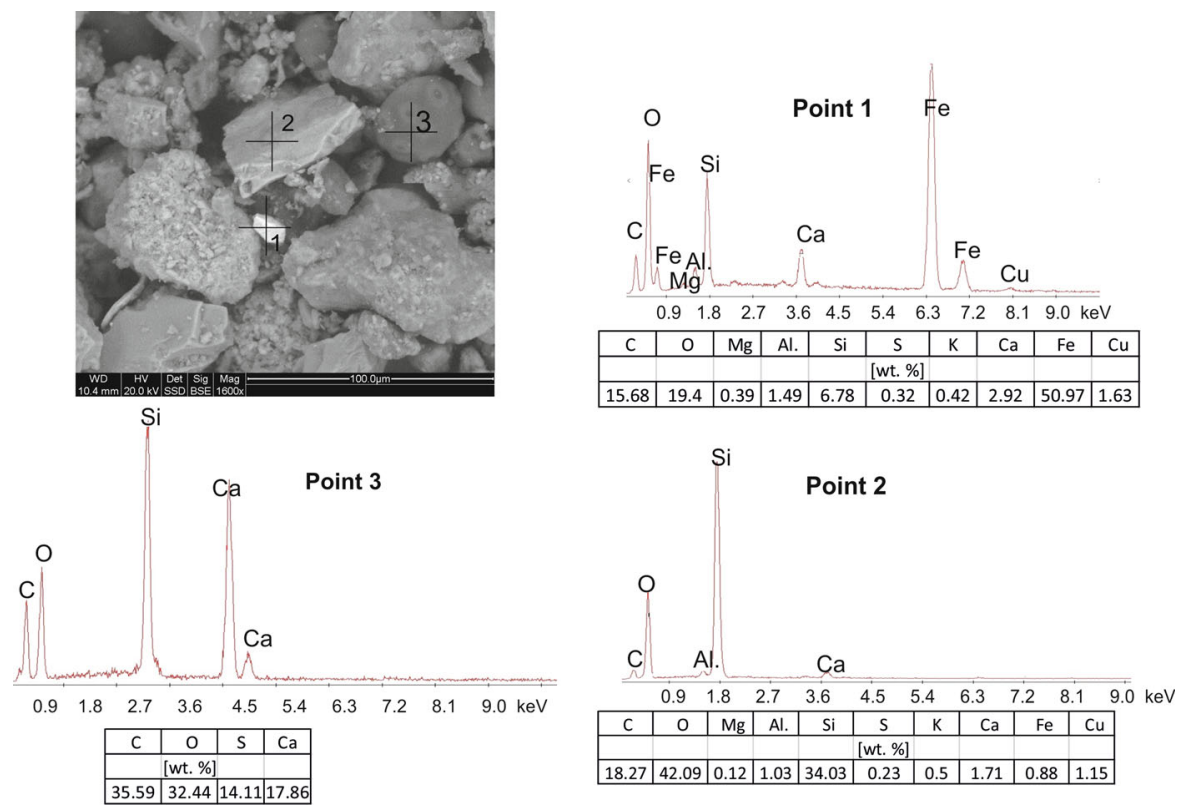

Fig. 4 SEM image with EDS spectra of the dust particles collected in the Jordan Park (2016)
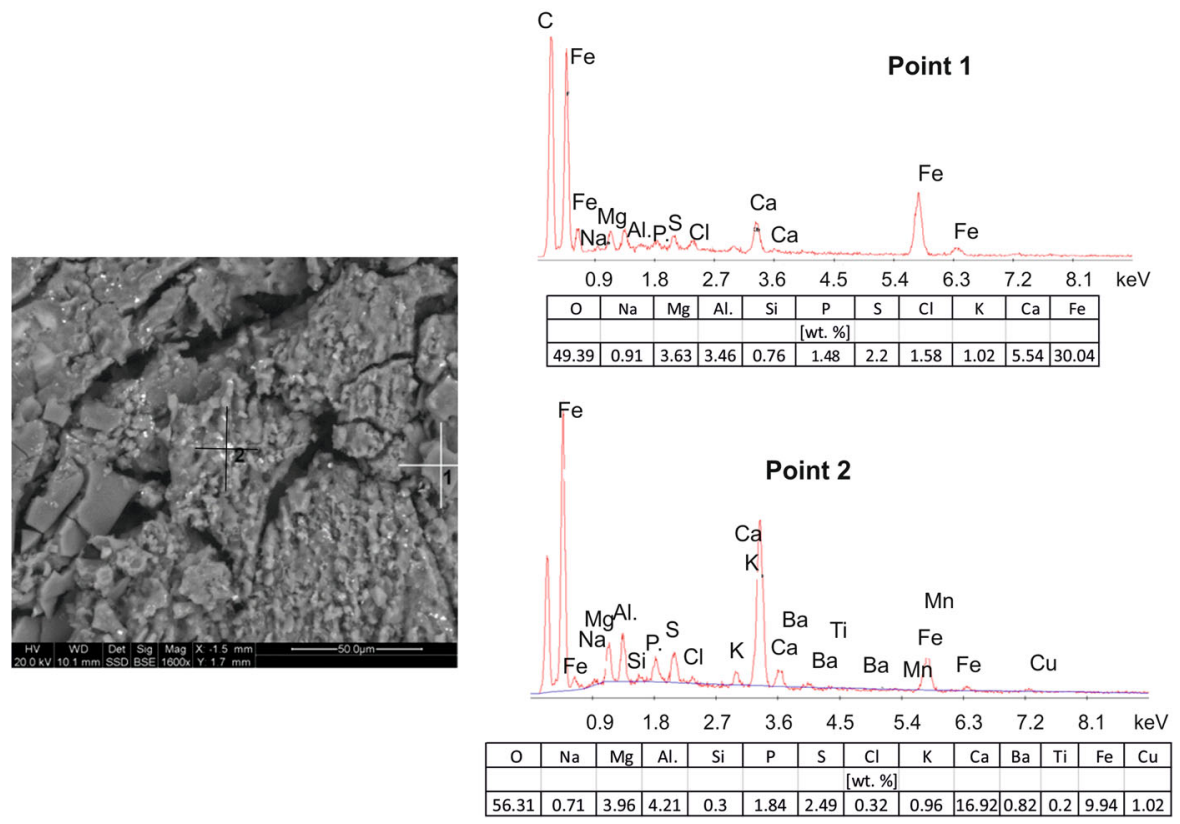

Fig. 5 SEM image with EDS spectra of the dust particles collected in the park in Nowa Huta (2015)

covered with fine needles of gypsum. Larger quartz grains have precipitation covers composed of cryptocrystalline mixtures mainly of $\mathrm{Fe}$ and $\mathrm{Mn}$ and of minor Mg oxide/hydroxides (point 1, Fig. 5). In many places were observed small metallic microspherules with the diameters below $5 \mu \mathrm{m}$ consisting mainly of $\mathrm{Fe}$ alloys with admixtures of $\mathrm{Pb}$ and $\mathrm{Ba}$ (point 2, Fig. 5). The metallic character indicates their origin in operations of the metallurgical plant located not far from the sampling site. 

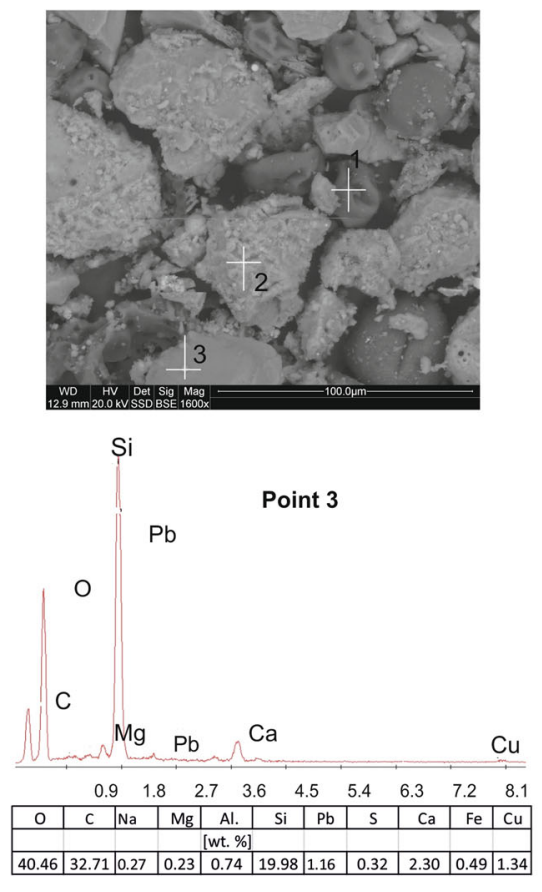

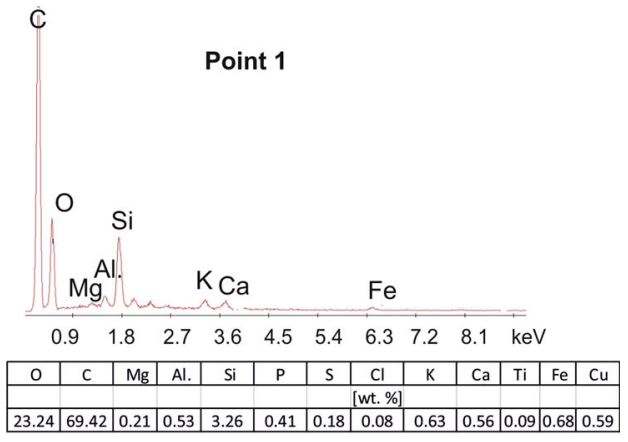

$\mathrm{S}$

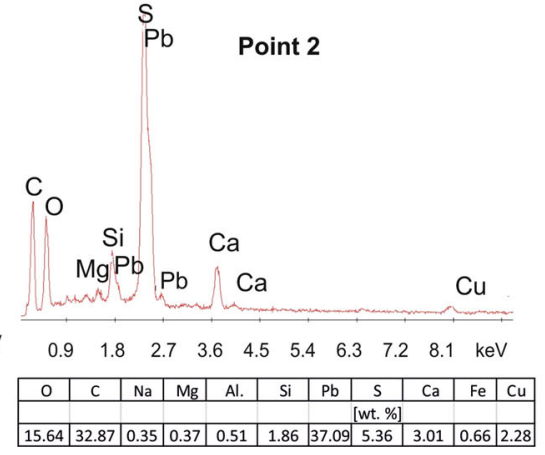

Fig. 6 SEM image with EDS spectra of the dust particles collected in the park in Pychowice (2016)

The dust particles collected in the Pychowice Park also have diversified sizes (Fig. 6). Larger grains (30-60 $\mu \mathrm{m})$ represent quartz and minor feldspars (points 2 and 3, Fig. 6), often covered with fine needles of gypsum. Spherical grains of smaller sizes (diameters 10-20 $\mu \mathrm{m}$ ), composed entirely of carbon, are products of unburned coal (point 1, Fig. 6). They are usually covered with tiny grains $(<1 \mu \mathrm{m})$ of other components, some of them being cryptocrystalline mixtures of oxides and/or oxide/hydroxides of various metals, mainly of Fe and Mn.

\section{Chemical composition of the urban dusts of Krakow}

Applying extraction of dust samples with a mixture of strong acids, the ICP-MS analysis provides data on an overall composition of the dust. A particular attention in current determinations was paid to selected heavy metals/metalloids that even if occurring in trace amounts are toxic to living organisms.

The dominant elements in the acid extracts of dusts of the Jordan Park, i.e. close to the city centre
(Table 2), are of the rock-forming type: $\mathrm{Ca}, \mathrm{Al}, \mathrm{K}, \mathrm{Mg}$ and Si. Their quantities in the dusts collected in the park no II of the industrial Nowa Huta district are distinctly lower. The proximity of the Arcelor steel works is confirmed by the highest contents of $\mathrm{Fe}$ (0.74-4.02 wt\%). Such a distribution of the elements was previously reported by Kicińska-Świderska (1999) and Samek et al. (2016). The lowest quantities of the rock-forming elements occur in the extracts from the Pychowice park area (site no. III), being three times lower than those of the Jordan Park, (site no. I).

The mean contents of $\mathrm{Fe}, \mathrm{Ca}, \mathrm{Si}, \mathrm{Al}, \mathrm{Mg}$ and $\mathrm{K}$ : $2.17,1.01,0.78,0.53,0.38$ and $0.23 \mathrm{wt} \%$, respectively, were calculated for all samples of each of the parks. The most differ the Si values: their variability coefficient $V$ is 1.53 . In the case of the remaining rockforming elements, their $V$ values are between 0.43 and 0.59. The method applied, which suits best the extraction of metallic elements, is insufficient to break down completely silicates and aluminosilicates; therefore, the quantities of $\mathrm{Si}$ and $\mathrm{Al}$ should be treated as largely underestimated.

Selected metallic and metalloid trace elements (Ba, $\mathrm{Cd}, \mathrm{Co}, \mathrm{Cr}, \mathrm{Hg}, \mathrm{Mn}, \mathrm{Na}, \mathrm{Ni}, \mathrm{Pb}, \mathrm{Ti}, \mathrm{Tl}, \mathrm{Zn}$ and $\mathrm{As}$ ) 
represent a particular group in environmental considerations. Most of them are toxic, and even their low concentrations cause illness symptoms, while at higher concentrations they may be lethal. The socalled death group is composed of $\mathrm{As}, \mathrm{Tl}, \mathrm{Cd}$ and $\mathrm{Pb}$, all of them being carcinogens. The airborne park dusts contain As in the range between 5 and $123 \mathrm{mg} / \mathrm{kg}$ (the mean of all the samples is $75 \mathrm{mg} / \mathrm{kg}$ ). The highest As contents (up to $123 \mathrm{mg} / \mathrm{kg}$ ) occur in the dusts of the Jordan Park (park no I) located in the city centre, medium ones in a modern housing district of Pychowice (up to $107 \mathrm{mg} / \mathrm{kg}$ ), and the lowest ones (5-31 mg/ $\mathrm{kg}$ ) in the industrial district Nowa Huta. Comparable dust contents of $\mathrm{Pb}$ with their mean $190 \mathrm{mg} / \mathrm{kg}$ were found in all three parks; however, the highest lead pollution range-213-258 $\mathrm{mg} / \mathrm{kg}$ - occurs in the Nowa Huta Park. The same trend is shown by the pollution with $\mathrm{Ni}$ and $\mathrm{Tl}$. The presence of these metals is associated with heavy traffic of vehicles: the combustion of car fuels and a normal exploitation wear being major reasons (Mazzei et al. 2008). Of other elements, the dust $\mathrm{Cd}$ contents are the highest in the Jordan Park (6-14 mg/kg), the lowest in the park in Nowa Huta $(1-5 \mathrm{mg} / \mathrm{kg}$ ) and the park in Pychowice $(5-6 \mathrm{mg} / \mathrm{kg})$. Except lead, the contents of two other metals in airborne dusts are the highest in the park of the Nowa Huta industrial district: 561-1891 mg/kg Zn and $3-140 \mathrm{mg} / \mathrm{kg}$ Co.

The general load of metals contained in the airborne dusts is the heaviest in the town centre, which refers to $\mathrm{Mn}, \mathrm{Na}, \mathrm{Ba}, \mathrm{Ti}, \mathrm{Cd}, \mathrm{Cr}$ and $\mathrm{Hg}$. The pollution is a result of an almost continuous movement of vehicles along major Krakow thoroughfares and the low emissions, i.e. the emissions caused by burning hard coal and coal products in households and small boiler houses (Samek et al. 2016). The industrial district Nowa Huta has its air loaded with the dusts carrying $\mathrm{Zn}$ and $\mathrm{Co}$, the elements attributed to steel-making operations. The dust contents of $\mathrm{Pb}, \mathrm{Tl}$ and $\mathrm{Ni}$ in the living district Pychowice, elevated in respect to other districts, must be linked to an intensive traffic.

The results of chemical determinations were subjected to cluster analysis in order to separate elements that form uniform statistical sets of their population in airborne dusts (Fig. 7). Two distinct sets have been distinguished.

The set $\mathrm{I}$ is composed of $\mathrm{Al}, \mathrm{K}, \mathrm{Mg}, \mathrm{Ca}, \mathrm{Si}$ and $\mathrm{Fe}$, which can be considered geogenic elements. Their presence results from wind-blowing (quartz) and weathering (mainly aluminosilicates) of various primary minerals, and in the case of $\mathrm{Fe}$ its anthropogenic contribution should be recognized because of the proximity of the steel works to the park in Nowa Huta. The set II consists of As, $\mathrm{Cr}$ (the two strongly related to each other), $\mathrm{Co}$ and $\mathrm{Ni}$. Their source is anthropogenic, most often attributed (Mazzei et al. 2008) to the movement of vehicles. The presence of $\mathrm{Cd}, \mathrm{Hg}$ and $\mathrm{Tl}$ is a result of both the car fuel combustion and the low emission. The remaining elements: $\mathrm{Ba}, \mathrm{Mn}$. $\mathrm{Pb}, \mathrm{Ti}, \mathrm{Na}$ and $\mathrm{Zn}$ may have their sources in the operations of the Arcelor steel plant of Krakow and also of other metallurgical facilities located some $35 \mathrm{~km}$ to the west (processing $\mathrm{Zn}-\mathrm{Pb}$ ores in Bukowno-Olkusz) and even of such facilities located farther to the west in Upper Silesia $(80 \mathrm{~km})$. The western direction is important to be mentioned as it is the prevalent direction of winds recorded in Krakow.

\section{Health risk assessment}

High concentrations of the contaminants in the dusts (Table 2) indicate two kinds of hazards endangering health and even life of Krakow residents. The toxins may enter the human organism mainly by inhaling the finest dusts of the $<\mathrm{PM}_{2.5}$ group and from lungs are distributed with blood into other organs. Additional amounts of deleterious elements can be absorbed by the children playing and walking in the open, mainly by putting dirty hands into their mouths.

To obtain comparative numerical data, certain assumptions based on the reports of the World Health Organization (WHO) $(1982,1993,1994)$ and US Environmental Protection Agency (EPA) (1986) recommendations were accepted. They served to establish average daily doses (ADD) of toxic elements contained in the urban dusts, from which the hazard quotient (HQ) values were calculated (Table 3) according to the expression (1). The health risk has been assessed for two age groups: children (6 years old, with the body mass $15 \mathrm{~kg}$ ) and adults (70 years old, with the body mass $70 \mathrm{~kg}$ ). The HQ values of the two groups considerably differ, due mainly to the lower body mass of children. The health risk of the youngsters exposed to high trace metal concentrations in the park dusts has been ranked in the following order of the HQ values: 


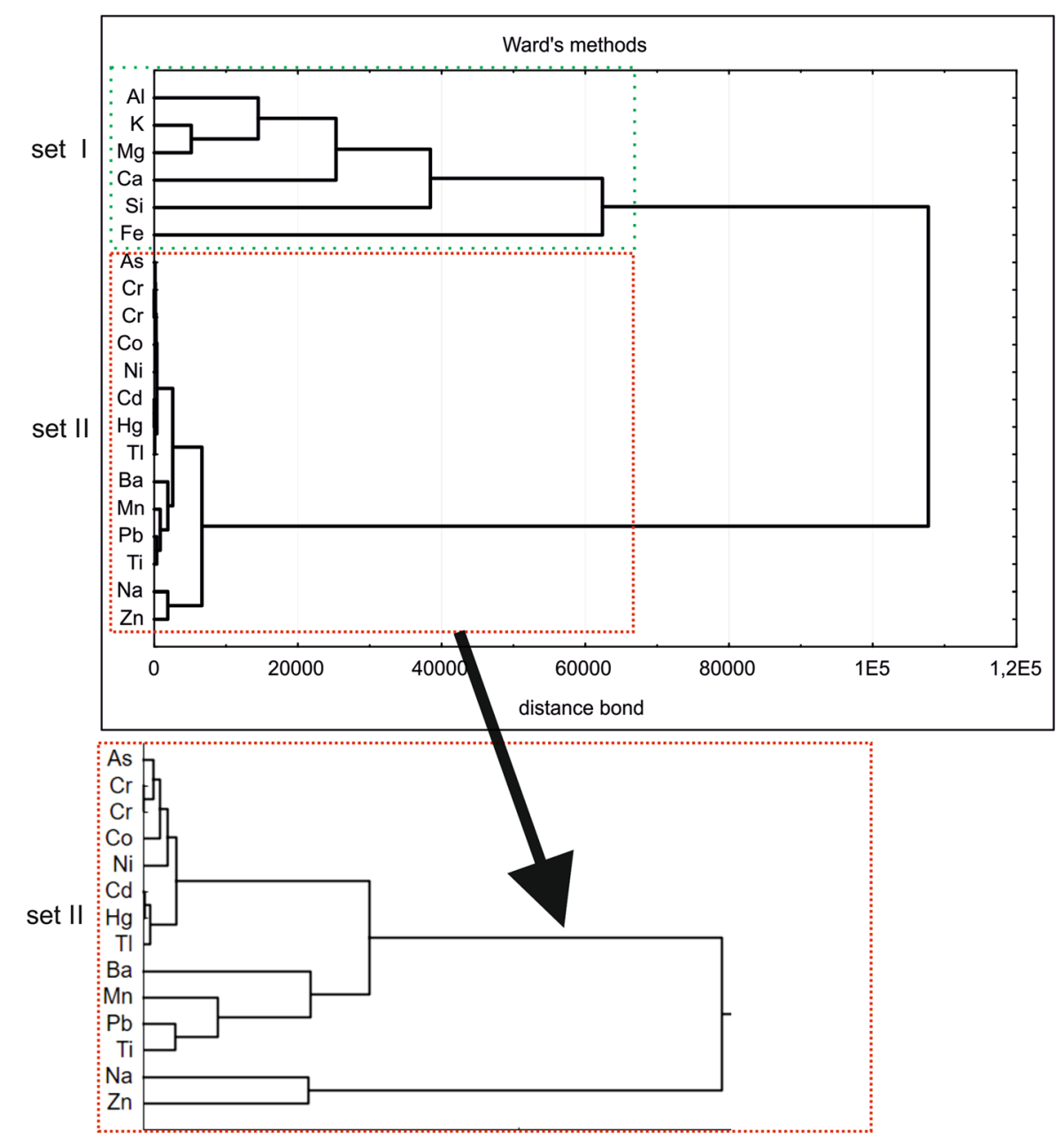

Fig. 7 Dendrogram for specified elements content in urban atmospheric dust samples from Cracow

As $=3.19 \mathrm{E}+00>\mathrm{Tl}=2.79 \mathrm{E}+00>\mathrm{Fe}=8.86 \mathrm{E}-$ $01 \cong \mathrm{Pb}=6.96 \mathrm{E}-01$. The $\mathrm{HQ}$ values of the remaining elements considered indicate low health risk.

The fact that almost all of the elements considered form compounds that are highly toxic and also cause cancerous changes of organisms exposed to their presence is even more disturbing (IARC 1990). Arsenic $\left(\mathrm{As}^{3+}\right.$ and $\left.\mathrm{As}^{5+}\right)$ belongs to the group I of carcinogenic elements according to the International Agency for Research on Cancer IARC (1987), and its long-lasting nutritional and inhaling exposition results in skin changes and affects functioning of the circulatory, nervous and respiratory systems (KabataPendias and Szteke 2012). Thallium has a negative impact on the heart and also on the digestive, nervous and respiratory systems. It is a cellular poison (KabataPendias and Szteke 2012) disturbing the cellular equilibrium and results in a general poisoning of the organism.

The HQ values applicable to adults are of a lower health impact those of children. The results indicate a possibility of adverse health effects of As $(\mathrm{HQ}=3.42 \mathrm{E}-01)$ and $\mathrm{Tl}(\mathrm{HQ}=3.00 \mathrm{E}-01)$ carried by urban dusts. If a daily dose of $200 \mathrm{mg}$ of the accidentally swallowed soil or dirt containing urban dusts is unquestionable for children, a dose of $100 \mathrm{mg}$ for adults seems to be slightly overestimated.

It should be stressed that the calculations have omitted the metals entering the human body through 
Table 3 Hazard quotient (HQ) and average daily dose $(A D D)$ calculated for adults and children
According to WHO

(1982, 1993, 1994)

$B W$ body mass, $E D$ exposure duration, bolded HQ exceeding one unit

${ }^{a}$ RfD (reference dose) according to IRSIS US EPA (1986) or calculated as per cent of PTWI (permitted tolerable weekly intake)

\begin{tabular}{|c|c|c|c|c|c|}
\hline \multirow[t]{2}{*}{ Element } & \multirow[t]{2}{*}{$\mathrm{RfD}^{\mathrm{a}}$} & \multicolumn{2}{|c|}{$\begin{array}{l}\text { Children } \\
\mathrm{BW}=15 \mathrm{~kg}, \mathrm{ED}=6\end{array}$} & \multicolumn{2}{|c|}{$\begin{array}{l}\text { Adults } \\
\mathrm{BW}=70 \mathrm{~kg}, \mathrm{ED}=70\end{array}$} \\
\hline & & $\mathrm{ADD}(\mathrm{mg} / \mathrm{kg} /$ day $)$ & HQ & $\mathrm{ADD}(\mathrm{mg} / \mathrm{kg} /$ day $)$ & HQ \\
\hline $\mathrm{Al}$ & $1.00 \mathrm{E}+00$ & $6.78 \mathrm{E}-02$ & $6.78 \mathrm{E}-02$ & $7.26 \mathrm{E}-03$ & $7.26 \mathrm{E}-03$ \\
\hline As & $3.00 \mathrm{E}-04$ & $9.59 \mathrm{E}-04$ & $3.19 \mathrm{E}+00$ & $1.03 \mathrm{E}-04$ & $3.42 \mathrm{E}-01$ \\
\hline $\mathrm{Ba}$ & $7.00 \mathrm{E}-02$ & $5.76 \mathrm{E}-03$ & $8.22 \mathrm{E}-02$ & $6.17 \mathrm{E}-04$ & $8.81 \mathrm{E}-03$ \\
\hline $\mathrm{Cd}$ & $1.00 \mathrm{E}-03$ & $7.67 \mathrm{E}-05$ & $7.67 \mathrm{E}-02$ & $8.49 \mathrm{E}-06$ & $8.49 \mathrm{E}-03$ \\
\hline $\mathrm{Co}$ & $2.00 \mathrm{E}-02$ & $5.47 \mathrm{E}-04$ & $2.70 \mathrm{E}-02$ & $5.86 \mathrm{E}-05$ & $2.93 \mathrm{E}-03$ \\
\hline $\mathrm{Cr}$ & $3.00 \mathrm{E}-03$ & $8.22 \mathrm{E}-04$ & $2.74 \mathrm{E}-01$ & $8.81 \mathrm{E}-05$ & $2.94 \mathrm{E}-02$ \\
\hline $\mathrm{Fe}$ & $3.00 \mathrm{E}-01$ & $2.78 \mathrm{E}-01$ & $8.86 \mathrm{E}-01$ & $2.98 \mathrm{E}-02$ & $9.49 \mathrm{E}-02$ \\
\hline $\mathrm{Hg}$ & $3.00 \mathrm{E}-04$ & $1.94 \mathrm{E}-05$ & $6.50 \mathrm{E}-02$ & $2.08 \mathrm{E}-06$ & $6.92 \mathrm{E}-03$ \\
\hline Mn & $4.60 \mathrm{E}-02$ & $5.97 \mathrm{E}-03$ & $1.30 \mathrm{E}-01$ & $6.39 \mathrm{E}-04$ & $1.39 \mathrm{E}-02$ \\
\hline $\mathrm{Ni}$ & $2.00 \mathrm{E}-02$ & $7.77 \mathrm{E}-04$ & $3.90 \mathrm{E}-02$ & $8.33 \mathrm{E}-05$ & $4.16 \mathrm{E}-03$ \\
\hline $\mathrm{Pb}$ & $3.50 \mathrm{E}-03$ & $2.43 \mathrm{E}-03$ & $6.95 \mathrm{E}-01$ & $2.61 \mathrm{E}-04$ & $7.445 \mathrm{E}-02$ \\
\hline $\mathrm{Si}$ & $4.20 \mathrm{E}-01$ & $9.91 \mathrm{E}-02$ & $2.36 \mathrm{E}-01$ & $1.06 \mathrm{E}-02$ & $2.53 \mathrm{E}-02$ \\
\hline $\mathrm{Ti}$ & $1.00 \mathrm{E}+00$ & $2.86 \mathrm{E}-03$ & $2.86 \mathrm{E}-03$ & $3.07 \mathrm{E}-04$ & $3.07 \mathrm{E}-04$ \\
\hline $\mathrm{Tl}$ & $8.00 \mathrm{E}-05$ & $2.24 \mathrm{E}-04$ & $2.79+00$ & $2.40 \mathrm{E}-05$ & $3.00 \mathrm{E}-01$ \\
\hline $\mathrm{Zn}$ & $3.00 \mathrm{E}-01$ & $1.22 \mathrm{E}-02$ & $4.10 \mathrm{E}-02$ & $1.31 \mathrm{E}-03$ & $4.37 \mathrm{E}-03$ \\
\hline
\end{tabular}

the skin or via the inhaling system. Due to that, the real health risk must be considerably higher than the one presented here.

\section{Discussion}

The health impact caused by the trace metals potentially toxic to people exposed to dust in urban parks of Krakow and expressed by the HQ index (Table 3) shows that the HQ values for children and adults decrease in the same order: $\mathrm{As}>\mathrm{Tl}>\mathrm{Fe}>$ $\mathrm{Pb}>\mathrm{Cr}>\mathrm{Mn}$. The $\mathrm{HQ}_{\text {ing }}$ values of $\mathrm{As}$ and $\mathrm{Tl}$ for children are $3.19 \mathrm{E}+00$ and $2.79 \mathrm{E}+00$, respectively, whereas for adults they are considerably lower, around ten times: $3.42 \mathrm{E}-01$ and $3.00 \mathrm{E}-01$, respectively. It is an effect of a smaller, accidental intake of these elements accepted in the calculations $(100 \mathrm{mg}$ by adults, $200 \mathrm{mg}$ by children) and a higher body mass of adults. The $\mathrm{HQ}_{\text {ing }}$ values of $\mathrm{As}$ and $\mathrm{Tl}$ calculated for children of Krakow are significantly higher than those of other large agglomerations (Table 4), e.g. 1.13E-01 As established in Luanda (Ferreira-Baptista and De Miguel 2005), 6.32E-02 As and 1.29E-02 Tl in Madrid (Miguel et al. 2007), and 8.71E-02 As in Nanjing (Wang et al. 2016).
The $\mathrm{HQ}_{\text {ing }}$ values of $\mathrm{Al}, \mathrm{Ba}, \mathrm{Cd}, \mathrm{Co}, \mathrm{Fe}, \mathrm{Hg}$ and $\mathrm{Mn}$ obtained for the inhabitants of Krakow are higher by at least one order of magnitude from the figures published by Ferreira-Baptista and De Miguel (2005) for Luanda, Wang et al. (2016) for Nanjing, Du et al. (2013) for Beijing, and Miguel et al. (2007) for Madrid. In turn, higher than in Krakow health risk values for children were found in Beijing 7.72E-01 of $\mathrm{Cr}$ (Du et al. 2013) and in Nanjing 7.37E-01 of $\mathrm{Pb}$ (Wang et al. 2016), whereas the higher $\mathrm{HQ}_{\text {ing }}$ value than for Krakow adults Beijing (Du et al. 2013) only in the case of $\mathrm{Pb} 9.89 \mathrm{E}-02$.

High concentrations of $\mathrm{As}, \mathrm{Tl}, \mathrm{Zn}$ and $\mathrm{Cd}$ in the dusts of Krakow are associated without doubts with long-distance emissions from the Olkusz area (around $40 \mathrm{~km}$ west of Krakow), where lead and zinc deposits were mined as early as the twelfth century. The Olkusz emissions contain high quantities of $\mathrm{As}, \mathrm{Cd}, \mathrm{Tl}$ and other, often toxic elements and contaminate the air and the soil-plant system not only in the closest neighbourhood (Kicinska and Gruszecka-Kosiwska 2016).

The quantities of $\mathrm{Cr}$ in the dusts of Krakow are more than 2 times lower than those given by Wang et al. (2016) in Nanjing and comparable to those in Beijing (Du et al. 2013). They exceed 2-3 times the values determined in Luanda (Ferreira-Baptista and 


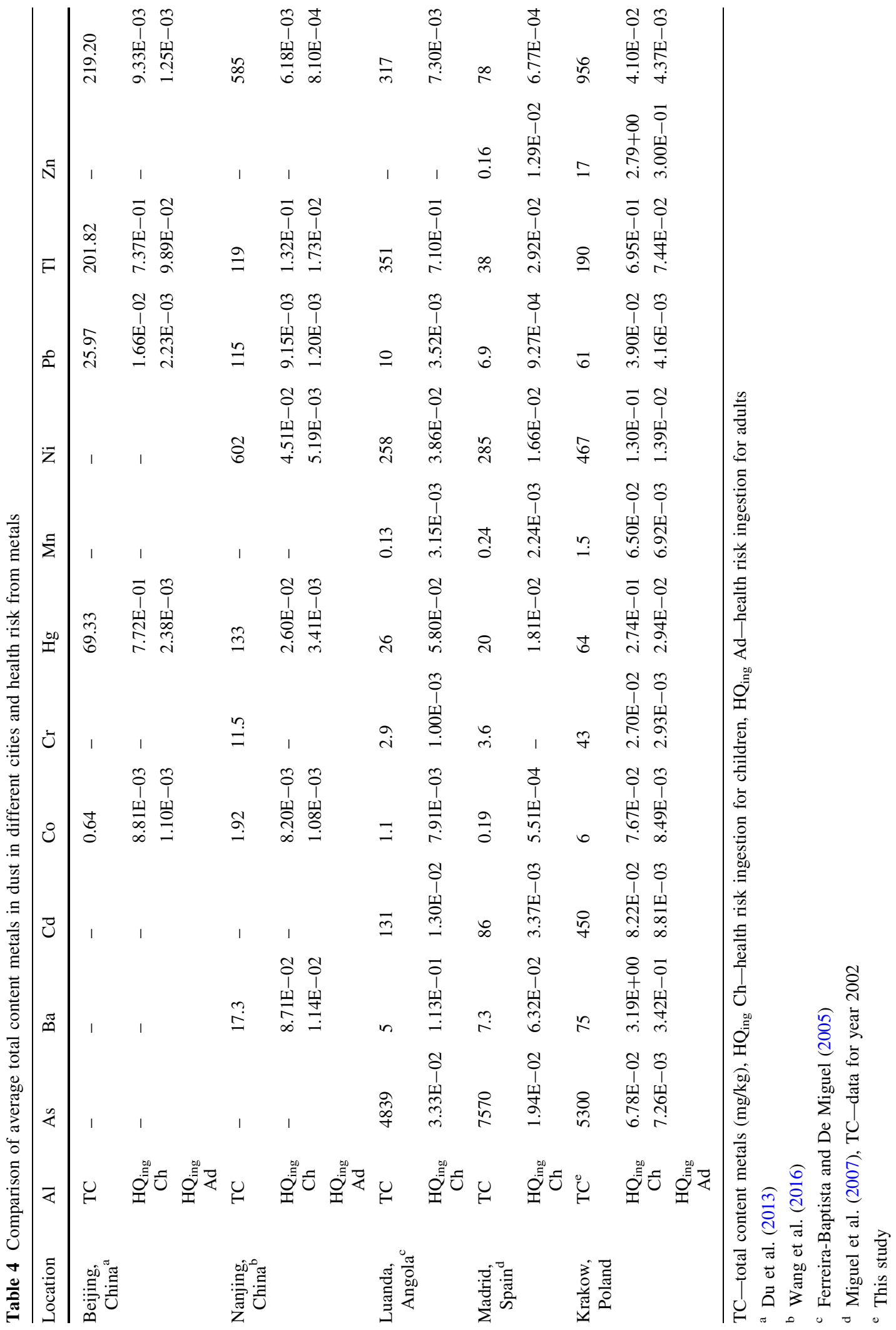


De Miguel 2005) and Madrid (Miguel et al. 2007). The quantities of Mn and Ni in the dusts of Nanjing (Wang et al. 2016) exceed those of Krakow. The quantities of $\mathrm{Pb}$ in the dusts of Luanda (Ferreira-Baptista and De Miguel 2005) are considerably higher than those of Krakow. The dust contents of $\mathrm{Al}$ in Madrid (Miguel et al. 2007) exceed only 1.5 times those noted in Krakow.

Another issue to be solved is the quantity of metals in the remaining seasons. The recalculation of the mean annual concentrations of elements in the air (Samek et al. 2016, see Table 2) indicates that they approximate most the spring mean concentrations (the only exception is $\mathrm{Ca}$ that dominates in the spring months). Therefore, it can be assumed that sampling carried out in the spring will give the most reliable and representative results for a town located in the same part of Europe as Krakow and with a moderate climate. As a result, the HQ index will be considerably higher during winter season than that determined in the summer. It must be remembered, however, that the winter time in this part of Europe does not favour playing in urban parks, thus assuming in calculations 2-h stays of children in playgrounds are definitely too high. The results obtained by Goudarzi et al. (2016) in the areas of the dry climate for sulphur compounds and airborne dusts are different than ours and indicate that the autumn is a better comparable period than spring.

\section{Conclusions}

The research material included urban dusts collected in three parks of Krakow, an agglomeration of a million of inhabitants. Their mineralogical and chemical analyses have provided the following conclusions.

1. The airborne dusts are considerably diversified considering their morphology, structural development, grain-size distribution and chemical composition.

2. Prevalent mineral phases include quartz and feldspars (geogenic minerals), also unburned coal remains (low emissions from households and small boiler houses) and gypsum (secondary phase of the anthropogenic origin). Other anthropogenic particles are metallic spherules, generated in metallurgical processes.
3. The presence of various hydrocarbons in the dusts of the three parks considered: i.e. of mineral oils and traces of benzines, results from combustion of motor fuels.

4. The chemical composition of the dusts, particularly their contents of $\mathrm{Cd}, \mathrm{Ba}, \mathrm{Ti}, \mathrm{Pb}, \mathrm{Zn}$ and $\mathrm{As}$, indicates a prevalently anthropogenic origin of contaminants.

5. High concentrations of heavy metals of the dusts are a significant factor of air pollution. The dust fallouts spread pollutants to soils, plants and surface waters and also directly affect the health of Krakow inhabitants.

6. The health quotients HQ $>10$ are a clear sign of a chronic exposure of children playing and walking in the Krakow Parks to As, Cr, Co, Ti and Tl. All these elements are highly toxic to humans, particularly to young organisms with a low body mass.

Acknowledgements Funding was provided by Akademia Górniczo-Hutnicza im. Stanislawa Staszica (Grant Nos. 11.11.140.199 and 11.11.140.319).

Open Access This article is distributed under the terms of the Creative Commons Attribution 4.0 International License (http:// creativecommons.org/licenses/by/4.0/), which permits unrestricted use, distribution, and reproduction in any medium, provided you give appropriate credit to the original author(s) and the source, provide a link to the Creative Commons license, and indicate if changes were made.

\section{References}

Boldo, E., Medina, S., LeTertre, A., Hurley, F., Mucke, H. G., Balleste, F., et al. (2006). Apheis: Health impact assessment of long-term exposure to PM2.5 in 23 European cities. European Journal of Epidemiology, 21, 4490458. doi:10.1007/s10654-006-9014-0.

DIN 38409-18 German standard methods for the analysis of water, waste water and sludge; Summary action and material characteristic parameters (Group H); Determination of hydrocarbons (H 18).

Du, Y., Gao, B., Zhou, H., Ju, X., Hao, H., \& Yin, S. (2013). Health risk assessment of heavy metals in road dust in urban parks of Beijing, China. Procedia Environmental Sciences, 18, 2990309. doi:10.1016/j.proenv.2013.04.039.

European Environment State and Forecasts. (2010). Synthesis. Copenhagen: The European Environment Agency.

Ferreira-Baptista, L., \& De Miguel, E. (2005). Geochemistry and risk assessment of street dust in Luanda, Angola: A 
tropical urban environment. Atmospheric Environment, 39, 4501-4512.

Goudarzi, G., Geravandi, S., Idani, E., Hosseini, S. A., Baneshi, M. M., Yari, A. R., et al. (2016). An evaluation of hospital admission respiratory disease attributed to sulfur dioxide ambient concentration in Ahvaz from 2011 through 2013. Environmental Science and Pollution Research, 23(21), 22001-22007. doi:10.1007/s11356-016-7447-x.

GUS. (2015). Central Statistical Office of Poland - Information Portal. Local Data Bank.

IARC. (1987). Arsenic and arsenic compounds. IARC Monographs, Suppl. 7, Lyon.

IARC. (1990). IARC Monographs on the evaluation of carcinogenic risk to human, 49, Lyon.

Jedrychowski, W., Perera, F., Maugeri, U., Spengler, J. D., Mroz, E., \& Raugh, V. (2008). Effect of prenatal exposure to fine particles and postnatal indoor air quality on the occurrence of respiratory symptoms in the first two years of life. International Journal of Environment and Health, 2(3/ 4), 314-329.

Kabata-Pendias, A., \& Szteke, B. (2012). Trace elements in geoand biosfere. Pulawy IUNG-PIB.

Khaniabadi, Y. O., Goudarzi, G., Daryanoosh, S. M., Borgini, A., Tittarelli, A., \& De Marco, A. (2016). Exposure to $\mathrm{PM}_{10}, \mathrm{NO}_{2}$, and $\mathrm{O}_{3}$ and impacts on human health. Environmental Science and Pollution Research. doi:10.1007/ s11356-016-8038-6.

Kicińska, A. (2016a). Health risk to children exposed to $\mathrm{Zn}, \mathrm{Pb}$, and $\mathrm{Fe}$ in selected urban parks of the Silesian agglomeration. Human and Ecological Risk Assessment: An International Journal, 22(8), 1687-1695. doi:10.1080/ 10807039.2016.1218271.

Kicińska, A. (2016b). Risk assessment of children's exposure to potentially harmful elements (PHE) in selected urban parks of the Silesia agglomeration. E3S Web of conference 10, 00035. doi:10.1051/e3sconf/20161000035.

Kicińska, A., \& Gruszecka-Kosiwska, A. (2016). Long-term changes of metal contents in two metallophyte species (Olkusz area of $\mathrm{Zn}-\mathrm{Pb}$ ores, Poland). Environmental Monitoring and Assessment, 188, 339. doi:10.1007/ s10661-016-5330-3.

Kicińska, A., \& Klimek, A. (2017). Risk of trace elements exposure for children playing in city parks of Cracow (Poland). Fresenius Environmental Bulletin (in press).

Kicińska-Świderska, A. (1999). Heavy metals in soils and plants in selected areas affected by impact the steel industry. $\mathrm{PhD}$ theses AGH UST, Kraków (in Polish).

krakow.pl/aktualnosci/.

krakow.pios.gov.pl/publikacje/raporty/raport11/3.

Leung, A. O. W., Duzgoren-Aydin, N. S., Cheung, K. C., \& Wong, M. H. (2008). Heavy metals concentration of surface dust from e-waste recycling and its human health implications in southeast China. Environment Science and Technology, 42(7), 2674-2680.

Mazzei, F., Alessandro, A. D., Lucarelli, F., Nava, S., Prati, P., Valli, G., et al. (2008). Characterization of particulate matter sources in an urban environment. Science of the Total Environment, 401, 81-89. doi:10.1016/j.scitotenv. 2008.03.008.

Miguel, E. D., Iribarren, I., Chacon, E., Ordonez, A., \& Charlesworth, S. (2007). Risk-based evaluation of the exposure of children to trace elements in playgrounds in Madrid (Spain). Chemosphere, 66, 505-513. doi:10.1016/j. chemosphere.2006.05.065.

Moreno, T., Querol, X., Alastuey, A., Reche, C., Cusack, M., Amato, F., et al. (2011). Variations in time and space of trace metal aerosol concentration in urban areas and their surroundings. Atmospheric Chemistry and Physics, 11, 9415-9430. doi:10.5194/acp-11-9415-2011.

Regulation of the Minister of the Environment of 9th September 2002. Dz.U. 2002 no. 165, item 1359 (in Polish).

Rzeszutek, M., Kasietczuk, M., \& Bogacki, M. (2014). Impact assessment of road transport on air quality in the selected area of Krakow. Logistic, 4, 4864-4873.

Samek, L., Stegowski, Z., Furman, L., \& Fiedor, J. (2016). Chemical content and estimated sources of fine fraction of particulate matter collected in Krakow. Air Quality, Atmosphere and Health. doi:10.1007/s11869-016-0407-2.

Skotak, K., Maziarka, D., Bratkowski, J., Jamsheer-Bratkowska, M., \& Krogulska, B. (2012). Environmental threats. In Health situation of the Polish population and its determinants. National Institute of Public Heath, PZH, Warszawa (in Polish).

Sustainability Report. (2014). ArcelorMittal Poland. http:// poland.arcelormittal.com/fileadmin/content/odpowiedzialny_ biznes/raporty/2014/ArcelorMittal_Poland_CSR_2015_pl. pdf.

US EPA. (1986). Guidelines for human health risk assessment of chemical mixtures. Federal Register (51 FR 34014-34025), Washington.

Wang, J., Li, S., Cui, X., Li, H., Qian, X., Wang, C., et al. (2016). Bio accessibility, sources and health risk assessment of trace metals in urban park dust in Nanjing, Southeast China. Ecotoxicology and Environmental Safety, 128, 161-170. doi:10.1016/j.ecoenv.2016.02.020.

Wcisło, E. (2009). Health risk assessment in the process of remediation of degraded lands chemically-The procedures and importance. Wyd. Ekonomia $i$ Środowisko, Biatystok, 29-63 (in Polish).

WHO. (1982). Safety evaluation of certain food additives and contaminants: Zinc. Food Additives. Series no. 17. Geneva.

WHO. (1993). Evaluation of certain food additives and contaminants. Technical report series 837, Geneva.

WHO. (1994). Concern for Europe's tomorrow. Health and Environment in the European Region. Summary.

WHO. (2016). http://maps.who.int/airpollution/.

WHO Regional Publication, European Series, 53, Copenhagen. Yu, L., Wang, G., Zhang, R., Zhang, L., Song, Y., Wu, B., et al. (2013). Characterization and source apportionment of PM2.5 in an urban environment in Beijing. Aerosol and Air Quality Research, 13, 574-582. doi:10.4209/aaqr2012.07. 0192.

Zhang, N., Han, B., He, F., Xu, J., Niu, C., Zhou, J., et al. (2015). Characterization, health risk of heavy metals, and source apportionment of atmospheric PM2.5 to children in summer and winter: an exposure panel study in Tianjin, China. Air Qual Atmos Health, 8, 347-357. doi:10.1007/s11869014-0289-0. 